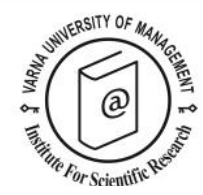

\title{
A conceptual justification and a strategy to advance community-based tourism development
}

\begin{abstract}
Andrea Giampiccoli ${ }^{1 *}$
${ }^{1}$ Durban University of Technology, Ritson Campus, Department of Hospitality and Tourism, P.O. Box 1334, Durban, 40oo, South Africa. Email: andrea.giampiccoli@gmail.com

${ }^{*}$ Corresponding author

Abstract

Inequality is growing across the globe. Tourism, as a major global sector with exceptional historical potential for growth and reach, is capable of substantially contributing to the fight against inequality. However, the current system is not doing so. This article, therefore, argues that community-based tourism (CBT) could equally contribute to reducing inequality and complement efforts towards redistribution. Based on extant literature and documents, this article aims to contribute knowledge on the relationship between tourism and development by justifying the CBT approach as one that favours redistribution. The article makes recommendations in support of the shift towards CBT principles.
\end{abstract}

Keywords: Tourism, Community-Based Tourism, Inequality, Alternative Tourism, Poverty

Citation: Giampiccoli, A. (2020). A conceptual justification and a strategy to advance community-based tourism development. European Journal of Tourism Research 25, 2503. 
Inequality is also an issue of social justice (UN, 2013, p. 22).

\section{Introduction}

Worldwide, tourism is contributing to economic growth and development in various ways (Ali, 2018, p. 417). While the development of this sector is uneven due to country-specific factors, it has experienced on-going, impressive growth since World War II (Bhat, 2018, p. 15; Signé, 2018, p. 2; Dluzewska \& Rodzos, 2018, p. 252) showing resilience in the face of economic turmoil and continuing its growth. It is a leading export sector in many emerging economies (UNWTO, 2018a, p. 6). In 2017, this sector was expected to account for 313 million jobs (9.9\% of total employment) and for $10.4 \%$ of global GDP (WTTC, 2018, p. 1). It contributes to employment and economic growth and enhances the growth of education, transportation and infrastructure in general (Ali, 2018, p. 417). The overarching goal of this article is to provide a conceptual justification and a strategy that advances the development of community-based tourism. Concomitant to its overarching goal, this article has two objectives: namely, to manifest the relationship between tourism and inequality; and to unpack the importance of CBT as an alternative tourism development approach with potential to eventuate redistributive effects.

Given the growth and current value of the tourism sector, it would seem reasonable to propose that it should participate, and indeed be a major player, in the struggle against poverty and inequality. The 2012 United Nations Conference on Trade and Development in Doha underlined the fundamental relationship between sustainability and the tourism sector's potential to promote inclusive and sustainable development, particularly for emerging countries (UNWTO, 2018b, p. 12; see also GarzaRodriguez, 2019, p. 2). It is also important to note that sustainable socio-economic change is achievable if local people share in the benefits and opportunities emanating from tourism (Mogale \& Odeku, 2018, p. 10). If tourism is to be a major player in promoting development, there needs to be a shift in ownership and control of this sector. In this context it is also important to emphasize that tourism operates within a global neoliberal hegemonic framework (Chok, Macbeth, \& Warren, 2007; Saayman \& Giampiccoli, 2016) supported by international institutions such as the World Bank (WB) and International Monetary Fund (IMF) that promote free trade, debt restructuring, capital accumulation and deregulation (Mowforth, Charlton \& Munt, 2008, p. 46).

The literature on the role of tourism in development has changed perspective over time. Initially, the main aim of tourism development was regional economic growth, with poverty alleviation considered a secondary objective or a 'natural' result through the trickle-down effect on local poor people (Saayman, Rossouw, \& Krugell, 2012, p. 463). However, the rewards of tourism and its positive and negative effects on the poor depend on which model of tourism development is selected (Saayman, Rossouw, \& Krugell, 2012, p. 463).

There is consensus that tourism has both positive and negative effects on local communities (Archer, Cooper \& Ruhanen, 2005; Nagarjuna, 2015, p. 14) and that the negative impacts are most apparent in emerging economies (Triarchi \& Karamanis, 2017, p. 40). Conventional/mass tourism is not working "towards more distributive measures" (Saayman \& Giampiccoli, 2016, p. 148). Furthermore, the sector continues to reproduce class and regional inequalities and causes economic, social and environmental problems (Tosun, Timothy, \& Öztürk, 2003, p. 133). Recognition of the negative effects of tourism, named "mass tourism", "conventional/commercial tourism" or "traditional tourism", has given rise to the birth and development of alternative forms of tourism (Triarchi \& Karamanis, 2017, p. 40). The growth of environmental awareness during the 1980s led to the application of the concept of sustainable development to tourism (Archer, Cooper \& Ruhanen, 2005, p. 95). Literature 
acknowledges the need to involve members of local communities in all aspects of tourism development (Nagarjuna, 2015, p. 14). Alternative tourism, which includes CBT, could produce better results (Giampiccoli \& Saayman, 2014, p. 1667), particularly in disadvantaged communities, it is not a 'panacea' for development (Saayman \& Giampiccoli, 2016, p. 146).

Community-based tourism (CBT) emerged to counter the negative effects of conventional/mass tourism (Gadi Djou et al., 2017, p. 16; López Guzmán, Sánchez-Cañizares \& Pavón 2011, p. 73) and "as a counterweight to neo-colonialism, neo-liberalism and conventional mass tourism” (Tolkach \& King, 2015, p. 389). However, there is a need to increase "recognition of context in CBT analysis" (Mayaka, Croy \& Cox, 2019, p. 177). A recent study in Bali found that, in light of the negative impacts of massbased tourism, there was a shift towards more sustainable forms of community-based tourism (Khamdevi \& Bott, 2018, p. 8).

Given the fact that inequality is growing worldwide, and that, the tourism sector as it is currently structured is not addressing this scourge, and, indeed, could be exacerbating it, this article explores how CBT, which incorporates redistribution, could contribute to the fight against inequality. This implies that the sector should adopt a more egalitarian and redistributive approach. The article proposes a strategy to shift tourism practices in a CBT direction, influencing and circumscribing the entire sector. This article argues for the need to go a step further and consider issues of control and ownership of this sector. The literature notes that, when inequality persists for a prolonged period, social discord increases. Policies and strategies are thus required to reduce or eliminate it (Acheampong, 2016, p. 2). This article argues that the tourism sector should align more with CBT theory, principles, characteristics and practices (Giampiccoli \& Saayman, 2016, p. 2) for the production of outcomes that benefit the most number of people involved in it.

\section{Research Methodology}

This article is a result of compiling information from secondary sources such as academic papers and documents from organizations/institutions. It is a conceptual offering that aims to contribute to the debate on the role of tourism in development while paying special attention to the potential role of CBT in addressing inequality.

Literature relating to inequality and the relationship between tourism, inequality and CBT was analysed. This literature was gathered from a number of academic websites such as ScienceDirect and IngentaConnect including Google Scholar. A general Internet search yielded source documents from relevant institutions/organisations (such as the World Tourism Organization - UNWTO). Different keywords such as 'global inequality', 'community-based tourism', 'community-based tourism inequality', 'community-based tourism poverty alleviation' and “community-based tourism redistribution' were useful in this search. The search included all years. However, a deliberate effort was made to use documents that are more recent. In a cost benefit analysis, the benefits outweighed the costs in using secondary data over primary data. This informed the choice of using secondary data to obtain an overview of tourism growth juxtaposed with inequality.

While it is less costly and less time-consuming to gather secondary data than primary data, it can require more attention in its interpretation and filtering. Internet search (using keywords) and document analysis were an appropriate methodology for this article, because it is conceptual work based on overall socio-economic and tourism trends relating to inequality and the tourism sector's role in addressing inequality. 


\section{Literature review}

Inequality

Inequality is a global phenomenon and levels of inequality are increasing in both advanced and emerging economies (Derviş \& Qureshi, 2016, p. 2). While income disparities decreased between the 1920 s and the 1970 in much of the world, since the 1970s inequality has grown almost everywhere (Alvaredo et al., 2018, p. 68). For example, despite China's healthy economic growth, inequality amongst its citizens has increased sharply since the 1980 os (Alvaredo et al., 2018, p. 11). Furthermore, even with confident growth expectations, in developing countries that adopt a 'business as usual' approach, income inequality will continue to grow (Alvaredo et al., 2018, p. 18).

Inequality and poverty are related and the former can influence the latter in various ways. Economic inequality renders it difficult to fight poverty (Yang, 2018, p. 21). Furthermore, inequalities (note the plural as there are many inequalities beside economic income) can impede progress in alleviating poverty (UN, 2013, p. 22). Increased levels of inequality in many countries since the 1980 os have delayed progress in decreasing poverty and sharing prosperity (UN, 2019, p. 87). Thus, "Inequality is also an issue of social justice" (UN, 2013, p. 22).

The relationships between tourism, poverty and inequality lend themselves for viewing in a global context. In developing countries, development strategies are often fashioned by external forces that ignore the local context, local people's involvement and indigenous models (Sofield, 2003, p. 88). It is difficult to employ tourism as a development tool in disadvantaged contexts when localities find themselves locked in a dependency framework controlled by global hegemonic forces (Giampiccoli, 2010, p. 93). Tourism should facilitate community self-reliance and independence. Given that this sector has relatively low financial entry requirements, it has the potential to involve the lower strata of society. Often, local actors face marginalisation from external actors who have superior resources (Saayman \& Giampiccoli, 2016, p. 163; Telfer, 2002, p. 123). In a context of conventional mass tourism, the potential role and relevance of small tourism companies is jeopardised (Koens \& Thomas, 2016, p. 1651; Rogerson, 2004, p. 15). A case study in the Low Country of South Carolina (USA) concludes that, despite the positive economic effects of tourism, it also has negative impacts which are "felt almost exclusively by the indigenous people" (Faulkenberry et al., 2000, p. 87). Thus, the economic benefits to local communities "correlate closely with the degree of direct control local residents have over the industry" (Faulkenberry et al., 2000, p. 87). The poor serve as a cheap source of labour for externally controlled companies, creating dependency (Faulkenberry et al., 2000, p. 87).

While control of the tourism sector is a key issue in determining its local impact, the tourism model rather than tourism itself is important. Different tourism development models favour some actors and side-line others and will produce different impacts and benefits in the local context. Local control, ownership and management of the tourism sector would enhance local community development and benefits as well as promote a more sustainable form of tourism, as local people will arguably be more aware and willing to nurture and protect their environment.

Studies on the relationship between tourism and poverty and/or inequality have produced mixed results (Bakker, 2018; Braun \& McLees, 2012; Folarin \& Adeniyi, 2019; Hampton, Jeyacheya \& Long, 2018; Kinyondo \& Pelizzo, 2015; Petit, 2017; Risso, 2018). However, there is a paucity of research on the connection between income inequality and tourism (Raza \& Shah, 2017, p. 3). It is assumed that, "first... tourism development indelibly leads to economic growth, and... second... economic growth can effectively reduce poverty" (Gartner \& Cukier, 2012). Nonetheless, tourism's effectiveness as a tool for poverty alleviation is debatable (Holden, Sonne \& Novelli, 2011, p. 317). Indeed, under certain 
conditions, it can exacerbate poverty (Gartner \& Cukier, 2012, p. 561). Tourism development can negatively affect the poorest strata of the population if certain steps (such as in education) are not taken (Saayman, Rossouw \& Krugell, 2012). Tourism can stimulate the development of a "culture of servitude" (Faulkenberry et al., 200o). A Tanzanian case study argues that economic growth is not sufficient to decrease poverty and inequality and "the only way it can reduce poverty is through suppressing income inequality something that is not always the case when economic growth occurs" (Kinyondo \& Pelizzo, 2018, p. 17). In order to reduce poverty and inequality, economic growth must be sustainable and inclusive (Niemhom, 2018, p. 9).

The aforementioned Tanzanian study also notes that while the expansion of tourism stimulated employment and economic development, the effects of tourism-induced growth were much less visible in terms of inequality (Kinyondo \& Pelizzo, 2015, p. 76). Three factors that undermine the sector's potential to reduce poverty and inequality are foreign ownership, vertical integration and poor remuneration packages for tourism workers (Kinyondo \& Pelizzo, 2015, p. 76). Based on this evidence, the poor seem to be the most negatively affected. It can be surmised that tourism development has the potential to intensify remuneration inequality (Petit, 2017, p. 25). As such, the tourism sector can thus be "exclusive' in its character, operations and impacts" (Rogerson, Benkenstein \& Mwongera, 2018, p. 5). Braun and McLees (2012, p. 436) show how the neoliberal development approach in Lesotho intersects with tourism to increase inequality by undermining local control. The adoption of a neoliberal capitalist growth model in the sector results in "inequity and injustice" (Higgins-Desbiolles et al., 2019, p. 16). This extends to alternatives such as ecotourism (Neth, Rith \& Knerr, 2008; Fletcher \& Neves, 2012). Duffy (2015) argues that nature based tourism can be a 'key driver of neoliberalism', camouflaging the inconsistencies between monetary growth and environmental sustainability and thus enabling novel sources of neoliberal accumulation (Duffy, 2015, p. 2). In Nicaragua, "tourism-embedded in [the] ... promise of economic growth as a vehicle for gaining competitive advantage and as a poverty reduction strategy-is not effective for those whose daily lives depend on more than play and fun" (Reyes, 2011, p. 28). The next section presents inequality from an African perspective.

In Tanzania, policy changes to enable more local people to enjoy the economic benefits of tourism are under consideration (Kinyondo \& Pelizzo, 2015, p. 76). A study conducted in Ghana noted that tourism has a very limited impact in the study area and there is a lack of policies specifically directed to include poor people in the process of tourism development (Holden, Sonne \& Novelli, 2011, p. 331). Within the current hegemonic neoliberal approach to tourism development, the role and contribution of tourism to redistribution is thus limited. However, it continues to be regarded as a redistributive strategy in countries like South Africa (Mogale \& Odeku, 2018, p. 1). It is against this background that this article proposes a policy shift towards inclusiveness based on CBT principles and characteristics. It argues that tourism should favor redistribution instead of enhancing inequality. It further argues that the sector needs remodeling around principles based on the local context and maximizing local benefits, with local community members leading the tourism development process.

\section{Towards new solutions and alternative tourism}

New, arguably more radical, solutions are necessary to ensure that tourism development is an effective tool to promote redistribution and reduce inequality. As the UNWTO (2018b, p.16) observes, tourism can boost local economies and create social opportunities. As such, this calls for new tourism development models that focus on inclusion. The World Economic Forum (WEF) concurs. It notes that its Inclusive Development Index 2018 points to the socio-political consequences of slow progress in improving living standards as well as widening inequality in both advanced and emerging 
economies. This has resulted in a general global agreement on the need for an inclusive growth and development model (WEF, 2018b, p. 1). The UN Under-Secretary-General for Economic and Social Affairs also notes that there is a global acknowledgment that growth without inclusion is not sufficient to reduce poverty (Hongbo, 2013, p. 7).

Inclusive tourism can be defined as, "Transformative tourism in which marginalized groups are engaged in ethical production or consumption of tourism and the sharing of its benefits" (Scheyvens \& Biddulph, 2018, p. 592). The focus is on the marginalized, including the very poor, women and girls, ethnic minorities and other groups that lack "power and/or voice" (Scheyvens \& Biddulph, 2018, p. 592). Community-based tourism is aimed at disadvantaged groups in society and should therefore be (it represents and goes beyond) a form of inclusive tourism that addresses the many global and local inequalities (not restricted to economic inequality, but extending to inequality in power, resources, knowledge, and access to services and so on).

However, the inclusive growth approach seems to have continued to reproduce the 'business as usual' framework within an "orthodox growth/neoclassical mode of analysis" (Hampton, Jeyacheya \& Long, 2018, p. 371). A study conducted in Vietnam concluded that inclusive growth resulting from tourism is not yet manifest because of the recent shift to capital-intensive development and the features and governance of current tourism initiatives (Hampton, Jeyacheya \& Long, 2018, p. 373). It notes that while there have been some local benefits, the market-led approach works against inclusive growth (Hampton, Jeyacheya \& Long, 2018, p. 373).

Alternative tourism is touted as the antidote to conventional tourism. Given that conventional/mass tourism reflects the capitalist ideology, alternative tourism emerged to counteract the power relations in this sector that promotes the interests of powerful stakeholders (Deville, Wearing \& McDonald, 2016, p. 423). However, many alternative tourism approaches such as pro-poor tourism (PPT) are embedded in the neoliberal system (Giampiccoli \& Saayman, 2014; Higgins-Desbiolles, 2008, 2018), while others such as CBT (Giampiccoli \& Saayman, 2014) and justice tourism (Higgins-Desbiolles, 2008) remain possible alternative forms. At the same time, CBT can also be circumscribed and embedded within a neoliberal framework, going against its original principles (Giampiccoli \& Saayman, 2014, p. 1674). It is evident that the original conceptualizations of the 1960s has been forgotten and usurped (Higgins-Desbiolles, 2008). In the current global socio-economic and policy context, alternative tourism approaches need to be remodeled for them to reclaim their original meaning to counteract conventional/mass tourism and its associated neoliberal discourse.

Furthermore, alternative tourism forms of tourism are often based on a voluntary code of conduct and self-regulation (Giampiccoli \& Saayman, 2014, p. 167). Matters are then left to the discretion of each enterprise and/or organization. It appears that PPT is designed to sustain the current neoliberal tourism system (see Saayman \& Giampiccoli, 2016). Its basic tenets seem to be sound, but are also patronizing as they assume that the knowledge and approaches adopted in developed countries' are applicable to developing countries (Fennel, 2006, p. 103). The corporatized tourism industry has usurped PPT as a public relations approach (Higgins-Desbiolles, 2008, p. 350). As a result, equity is downplayed (Schilcher, 2007, p. 167). Mahadevan, Amir and Nugroho (2017, p. 615) commented that current tourism development initiatives that adopt a pro-poor approach often embrace the trickledown theory that assumes that tourism expansion will enhance economic growth and that some of the benefits will eventually accrue to the poor. The failure of this logic has been used as a justification for government intervention in this sector (Schilcher, 2007, p. 173). Organizations and agencies that support PPT take a soft approach, proposing self-regulation and voluntary codes of conduct that 
result "in relatively small direct benefits for the poor, while continuing with a growth ethos that maximizes benefits to the non-poor" (Scheyvens, 2011, p. 221) and thus enhancing the inequality gap instead of decreasing it. This form of tourism can also be associated with corporate social responsibility (CSR) and codes of conduct that aim to avoid government regulation (Schilcher, 2007, p. 69). Other alternative forms of tourism are also embedded in the neoliberal framework.

A case study conducted in South Africa (Giampiccoli \& Saayman, 2017, p. 10) noted that, CBT places a burden on the poor as their tourism efforts are expected to be environmentally friendly, while in conventional tourism, this is a voluntary exercise rather than a requirement. In short, the historical and current structure of the tourism sector reveals the prospects and limitations of the responsible tourism approach to development (Mowforth, Charlton \& Munt, 2008, p. 46).

Conventional tourism poses many challenges. Leakage is a case in point. The typical import related leakage is calculated at between $40 \%$ and $50 \%$ of gross tourism earnings for small economies, and between $10 \%$ and $20 \%$ for more advanced and differentiated economies (Wiranatha, Antara \& Suryawardani, 2017, p. 3). A study conducted in Indonesia concluded that increased leakage will reduce economic growth and lead to increased income inequality among social groups (Wiranatha, Antara \& Suryawardani, 2017, p. 11). The authors (Wiranatha, Antara \& Suryawardani, 2017) noted that amongst other solutions, governments and tourism companies in destination areas should support locally-owned accommodation. The issue of local control is paramount. Ha Long Bay in Vietnam presents an example of the shift in control of tourism companies from national to foreign ownership following the expansion of tourism facilities and infrastructure that attracted investment by major foreign accommodation chains (Hampton, Jeyacheya \& Long, 2018, p. 368). This can give rise to increased leakage (Hampton, Jeyacheya \& Long, 2018, p. 368). Hampton, Jeyacheya and Long (2018, p. 367) argue that, "Small businesses operating in the formal and informal sectors are fundamental for inclusive growth because they sustain the livelihoods and communities of those typically underrepresented in government policies: that is, poor, marginalised and rural communities." It is likely that CBT would suffer a similar fate in Ha Long Bay. The shift from informal to more formal tourism development will marginalise the informal sector and small tourism companies and favour large companies (Giampiccoli \& Mtapuri, 2012, p. 34). While care needs is necessary to ensure that local elites do not capture control of tourism and its benefits, local ownership needs prioritisation as a way to distribute tourism ownership and benefits to the wider community and to decrease leakage. This would increase the economic benefits accruing to the local community as well as the number of people benefiting (directly or indirectly) from this sector.

Community-based tourism also has its own challenges, obstacles and limitations (Saayman \& Giampiccoli, 2016, p. 149). "If carelessly applied, CBT can create problems and even bring disaster upon the community" (Suansri, 2003, p. 7). It is important to understand CBT in its original formulation and intention to promote an alternative to conventional/mass tourism and to facilitate redistributions (note the plural - there many pertinent redistributions that must occur in society such as of wealth, power, resources, and so on). Thus, despite its problems, CBT remains the best approach to promote local development and encourage local participation in the tourism sector. Furthermore, also within sustainable tourism development, it is recognise that it is feasible if priority is given to local people (Gutierrez, 2019, p. 27; Okazaki, 2008; Moscardo, 2008:175).

The problems associated with CBT can stem from "the methods and techniques employed in its implementation" such as the top-down approach adopted by various actors (Sakata \& Prideaux, 2013, p. 882). Furthermore, CBT is negatively perceived (Government of Barbados, 2012, p. 10; Ndlovu, 
Nyakunu \& Auala, 2011, p. 39) and it has been suggested that the CBT name is 'unsellable!' (Suansri \& Yeejaw-haw, 2013, p. 9). In Thailand, it took years of work before CBT was accepted by various stakeholders (Suansri \& Yeejaw-haw, 2013, p. 9). The South African Department of Environmental Affairs and Tourism's White Paper on the Promotion and Development of Tourism in South Africa notes that, the tourism industry has negative perceptions of CBT and that "previously neglected people, their culture and their products often tend to be depreciated" (The Department of Environmental Affairs and Tourism, 1996, p. 13). This is also important in relation to community empowerment. For instance, in terms of ecotourism, it has been noted that psychological disempowerment can occur when people feel inadequate or inferior "or if they feel they have no control over the pace and direction of development" (Scheyvens, 2000, p. 239). Nonetheless, as discussed in the following section, the literature affirms that CBT principles can promote redistribution and decrease inequality.

\section{Community-based tourism: towards redistribution}

The definition of 'inclusive tourism' presented earlier in this article overlaps with the reasoning behind CBT that targets marginalised and disadvantaged groups in society (Tasci, Semrad, Yilmaz, 2013, p. 10). It follows that CBT addresses issues such as empowerment, self-reliance, social justice and sustainability (Giampiccoli, 2015). Thus, CBT has various principles and characteristics. Fundamentally, CBT is intended to counter, oppose and decrease inequality as it is linked to redistribution. One of its principles is "Equity in distribution of income and wealth, avoiding losers and winners (winners usually outsiders, exploiters)" (Tasci, Semrad, Yilmaz, 2013, p. 12). Communitybased tourism promotes "All-inclusive participation and equity in planning, decision-making, management, ownership, and distribution of benefits and costs" (Tasci, Semrad, Yilmaz, 2013, p. 22). It should not be understood from a neo-colonial perspective where enterprises are foreign owned, possibly excluding local people from its benefits (Ullan de La Rosa, Aledo Tur \& Garcia Andreu, 2017, p. 469). Community-based tourism is not built around external parties but is based on local community control, empowerment and benefits (Kaur, Jawaid \& Bt Abu Othman, 2016, p. 7). It should be built "upon the idea of collective ownership and management, redistribution of profits as well as ecological, social, and cultural preservation” (Ullan de La Rosa, Aledo Tur \& Garcia Andreu, 2017, p. 469). Community-based tourism works within a redistributive framework where, without denying the individual, the collective is at the heart of concepts and practices.

Dangi and Jamal (2008, p. 12) state that, "CBT thus very clearly identifies with distributive and social justice, ethical relationships and equity, from its rootedness in the locale/community." It must "benefit disadvantaged community members and bring about redistribution, social justice and empowerment" (Giampiccoli \& Saayman, 2018, p. 22). Community-based tourism strategies are associated with a complete restructuring of the tourism sector aligned with issues such as equity, social justice and community control (Saayman \& Giampiccoli, 2016, p. 151).

Community participation in CBT is linked to Arnstein's (1969, p. 216) notion of Citizen Participation that is "a categorical term for citizen power" which "is the redistribution of power that enables the have-not citizens, presently excluded from the political and economic processes, to be deliberately included in the future" (Giampiccoli \& Saayman, 2018, p. 22). It is fundamentally aligned to local control that can facilitate increased local benefits. The process of empowerment should follow a facilitative approach where local community members not only participate, but, own and control the tourism development process (Saayman \& Giampiccoli, 201, p. 154). Locally controlled CBT activities are fundamental to connect the macro-economic context with micro-level development (Akunaay Nelson \& Singleton, 2003, p. 9). Local ownership favours backward and forward linkages (Hampton, 
Jeyacheya \& Long, 2018, p. 362). Local economic linkages are fundamental to revive or develop specific localities or regions.

Community-based tourism's redistributive logic is also based on the fact that it has direct and indirect beneficiaries (Ndlovu and Rogerson, 2004, p. 446; Singh, 2008, p. 156; Sproule \& Suhandi, 1998, p. 216; Suansri, 2003, p. 69). Direct beneficiaries are those that are directly involved in CBT projects/ventures, while indirect beneficiaries would, for example, include local community members that benefit from development projects linked to CBT (Sproule \& Suhandi, 1998, p. 216). The funds generated by CBT ventures can be used for community projects (Pérez, et al., 2010:30; Asker et al., 2010, p. 44). Strategies to facilitate improved distribution of benefits include establishing CBT networks amongst localities that "could enhance ...powers of negotiation and increase sustainable tourism alliances" (Somnuek, 2018, p. 1030). Networks can be established at different geographical levels and involve a variety of entities such as non-governmental organizations (NGOs), the private sector and communities (Trejos, Chiang \& Huang, 2008, p. 17). Community-based tourism networks can enhance socioeconomic development, while traditional, neoliberal tourism makes a paltry contribution to local livelihoods (Tolkach \& King, 2015, p. 386). Community-based tourism networks can also serve to enhance the national CBT product (Tolkach, King\& Pearlman, 2011, p. 4). It is for this reason that an international CBT organization is proposed with decentralized branches (Giampiccoli \& Saayman, 2016, p. 8). Characteristics of CBT include participation by marginalised and disadvantaged groups in society in ownership, planning, controlling, management, decision-making of CBT ventures and projects and the distribution of costs and benefits equitably to bring about social justice, equity and empowerment.

\section{Comparative tourism framework for effects}

If tourism is to work effectively to decrease inequality at both local and global level, it cannot be small-scale and the aim should be to mainstream the CBT approach (Saayman \& Giampiccoli, 2016, p. 164). It should always prioritise disadvantaged community members and be loyal to its principles. Moreover, CBT should aim to influence the tourism sector as a whole to move towards its local control (Saayman \& Giampiccoli, 2016, p. 166). The literature (Calanog et al., 2012, p. 184; France, 1997, p. 17; Hamzah \& Khalifah, 2009, p. 2; Jealous, 1998, p. 12; Peaty, 2007, p. 74; Saayman \& Giampiccoli, 2016, p. 166) notes that CBT has the potential for scaling up. Two possible ways in which to achieve this are: increasing the size of tourism establishments, for example, bigger establishments such as resorts or hotels; and becoming the main (or only) actor in a geographical area. In relation to other forms of alternative tourism, it has been noted that, in order to be effective, "PPT must be integrated in a broad community-based development strategy" (Karim, Mohammad \& Serafino, 2012, no page) and alternative tourism such as ecotourism and PPT "should be integrated within the CBT approach and not vice versa, as neoliberalism's aim seems to be" (Giampiccoli \& Saayman, 2014, p. 1674). Thus, CBT should become the leading approach to tourism development.

Figure 1 proposes a relationship amongst the various issues raised so far namely inequality/poverty, conventional/mass tourism, alternative tourism, CBT and concentration/redistribution effects. While Figure 1 shows a linear relationship essentially proposing flexibility and openness to options allowed. Figure 1 proposes that conventional/mass tourism (that also includes various forms of alternative tourism) is not controlled by disadvantaged people and sustain concentration (as opposite to redistributive) effects (that is the concentration of wealth and power). Community-based tourism is controlled by disadvantaged people and advances redistribution effects that break inequality (showed in Figure 1 by the dotted - 'broken' - line). 


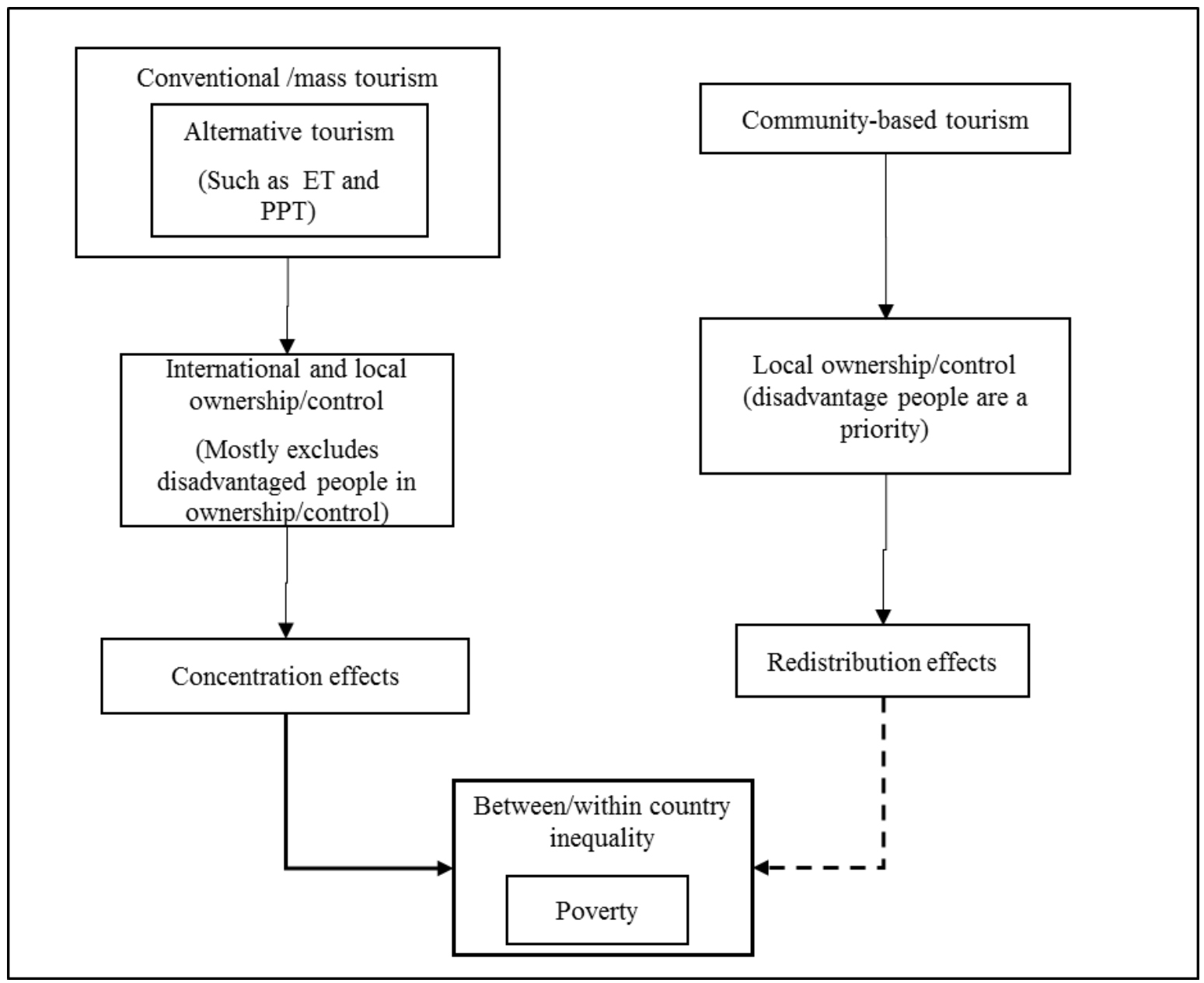

Figure 1. Proposed relationship between inequality/poverty, conventional/mass tourism, alternative tourism, CBT and concentration/redistribution effects.

Source: Author elaboration.

However, given that it operates in disadvantaged contexts, CBT usually requires external facilitation and assistance, and thus calling for partnerships with external entities. Various partnership models are possible, but arguments have also been made against external involvement (Dodds, Ali \& Galaski, 2016:5). It is the author's contention that while partnerships can add value, specific parameters should be set and CBT "ventures should remain fully owned, managed and controlled by community members [...] external partners should provide facilitative and other supporting services such as marketing and skills development and not be partners in the CBT ventures themselves" (Mtapuri \& Giampiccoli, 2013, p.5). It is expected that ventures should be fully controlled, owned and managed by disadvantaged community members. Various entities can be involved in partnerships with, or facilitate CBT projects and ventures including the private sector, NGOs and government entities (Dodds, Ali \& Galaski, 2016:10; Mtapuri \& Giampiccoli, 2016) and they can play different roles in CBT development (Giampiccoli, Saayman \& Jugmohan, 2014:1142; Mtapuri \& Giampiccoli, 2016:156). However, the government's role in CBT is regarded as fundamental (Connelly \& Sam, 2018:566; Mtapuri \& Giampiccoli, 2013:5; Mtapuri \& Giampiccoli, 2016:156; Tasci, Semrad \& Yilmaz, 2013:33). Government should be the main protagonist, whose task is to "formulate official definitions of forms 
of tourism in order to inform legislation and policy. This would also prevent stakeholders from formulating their own definitions in pursuit of their particular interests" (Mtapuri \& Giampiccoli, 2019:33). Given their characteristics such as a long-term presence, being - usually - not for profit - and their wide range of expertise, universities have also been proposed as possible key players in facilitating CBT development (Giampiccoli, Saayman \& Jugmohan, 2014:1149; see also Tasci, Semrad \& Yilmaz, 2013:33). They can offer accessible resources for "community change and sustainability" (Govender \& Giampiccoli, 2018:6).

\section{Discussion and a possible way forward}

Growing global inequality is a serious issue that calls for innovative solutions. A more proactive approach to social justice is required across all spheres including socio-economic. The size of the tourism sector and its global reach into the smallest localities and communities mean that it has much potential to contribute to the fight against inequality and poverty as well as to holistic community development. However, to date, it has struggled to live up to this potential.

Community-based tourism, which is rooted in the 1970's alternative development approach, proposes an alternative to conventional tourism that will enable this sector to play its rightful role in tackling inequality. However, its embeddedness in, or association with, the neoliberal framework in the form of approaches such as PPT has prevented it from fulfilling its potential. There is thus a need to differentiate CBT from other alternative tourism development approaches. While CBT has some characteristics that are found in other alternative tourism forms, its origins, initial aim and fundamental characteristics render it unique and distinctive in its possible role and contribution to fighting inequality within a redistributive context. Beyond differentiation, there is a need to institutionalise CBT at national and global levels based on its original conceptualisation and fundamental characteristics and to mainstream its implementation across the entire tourism sector. Furthermore, governments and international and national tourism bodies need to enhance the role, significance and potential of CBT.

While sustainable tourism, ET and RT have enjoyed wholesale acceptance (for example, the United Nations declared 2002 the International Year of Ecotourism and 2017 the International Year of Sustainable Tourism for Development), CBT remains in limbo and is regarded as either secondary or inferior and not as a full-fledged tourism type. This could also be because ecotourism and sustainable tourism have been co-opted and absorbed by neo-liberal theories and practice - if ever they were alternatives. In its original form, CBT stands opposed to the mainstream tourism approach. Despite suffering some co-option by neo-liberalism, there are many CBT projects and programmes that are not part of mainstream thinking. However, the NGOs and similar organisations that run CBT projects more often than not regard them as 'small projects' rather than as a strategy to change the entire tourism structure. If CBT is to contribute to the fight against inequality, it needs to be fully institutionalized as part of a strategy to restructure the tourism sector to make it more locally oriented and community controlled. What is required is a tourism sector based on CBT's original principles and characteristics. This article advocates for the mainstreaming of CBT as the main (ideally only) form of tourism, meaning that CBT principles, characteristics and practices should be the basis for any tourism development. Unfortunately, moves in this direction are counteracted by the actors that control the mainstream tourism approach that keeps CBT at the margins, a secondary charity oriented strategy, used more for public relations purposes than for real change.

A number of strategies could shift the tourism industry towards a CBT approach. These include: 
$\checkmark$ Standardising the definition of CBT. Confusion around the definition and characteristics of CBT needs to be overcome by providing clarity on what it is so that it will not be possible to exploit the concept by for example, 'marketing gimmick' strategies. The original conceptualisation of CBT should be adopted in order to avoid its co-option and collusion with neoliberalism. Again, CBT needs to be differentiated from other forms of alternative tourism such as PPT and RT.

$\checkmark$ Establishing international and national CBT organizations/networks. This will serve to institutionalise CBT at the global and local level and to promote recognition of CBT, and its principles, values and characteristics.

$\checkmark$ Including CBT in already established international and national tourism organisations, such as the UNWTO and national tourism bodies. Community-based tourism representatives should be part of the management structure of these organisations and should be involved in decisionmaking.

$\checkmark \quad$ Formulating an official classification of CBT ventures. As an 'independent' type of tourism, rather than a 'charity' or branch of conventional tourism, CBT needs its own classification so that the tourism industry as a whole and tourists themselves can distinguish the various CBT ventures. Classification should be related to level of 'luxury' of a CBT enterprise, but also, very importantly, the extent to which the venture is genuinely CBT. This can be done by establishing a classification system based on the principles and characteristics of CBT.

$\checkmark$ Education on CBT. Various stakeholders in the tourism sector and tourists need to be 'educated' on CBT. It should not only be part of higher education qualifications, but should be offered as a degree in itself (the same as an ecotourism or sustainable tourism qualifications). This would produce future tourism personnel with specialist knowledge of CBT. Education on CBT should also occur within communities to empower them to decide whether or not to implement it and their capacity to own and manage it.

$\checkmark$ Partnering CBT entities with private enterprises, organizations, the government sector and universities. While partnerships should each have their own specific regulations and rules, they can be fundamental to CBT projects, particularly in the initial stages. Higher education institutions such as universities would be particularly relevant partners.

$\checkmark$ Creating specific credit lines for CBT development and formulating policies and regulations to facilitate such. Funding is usually a major issue in CBT development.

$\checkmark$ Policies should set a maximum threshold for foreign companies' share in tourism. In specific localities, specific thresholds should be set for foreign ownership of tourism businesses. There is a power and capacity imbalance between large, often foreign, tourism enterprises and local ones, especially small and CBT type, businesses. Policies and regulations should prioritise local ownership and management of the tourism sector (issues in relation to the local elite also need to be considered).

While willingness to advance and implement these strategies will rely on specific people and institutions (and difficulties and resistance can certainly be foreseen), their implementation could serve to shift the tourism industry to a CBT milieu, making it more capable of addressing inequality and poverty and enhancing holistic community development. The current global and local tourism systems work against CBT. The mainstream tourism industry aims to continue working in the 'business as usual' mode, with small, voluntary 'gifts' to the environment and local people, rather than changing the system itself. An alliance of people and organisations at global and local levels is necessary to push for substantial change - beyond small local projects - of the tourism sector towards a more CBT, redistributive and egalitarian pattern of development. 
Given the size and reach of the tourism sector, it holds great potential to tackle the problem of growing global inequality. This article argued that the current structure of this sector prevents it from doing so. It advocated for the need to promote CBT and its associated principles at the local and global level. Community-based tourism should not be relegated to the margins, but should be advanced, scaled-up and ultimately institutionalised (see Giampiccoli \& Saayman, 2016). The aim should be a rebalanced tourism sector that works towards equality rather than perpetuating inequality. This article contributes to literature on the relationship between tourism and development specifically by justifying the need - and proposing solutions that advance CBT as a main global tourism type. The advancement of CBT aims at reducing inequality and poverty through exploiting the role of tourism as a major global economic player.

\section{Conclusion}

The article proposed strategies that could be adopted to kick-start the shift towards CBT. The intention is to institutionalise CBT principles so to entrench this form of tourism to become the mainstream approach. To achieve this goal some initial action should be for governments to establish specific CBT offices, universities to start specific CBT degrees and global tourism organisations to open specific CBT 'branches'. Thus, policy and managerial implications can include the elaboration specific policies and regulations for CBT. In addition, there is the need to make sure that what is written in the policies reaches disadvantaged people (that is CBT projects). Importantly, the monitoring and evaluation system needs to be put in place so that CBT has proper quality standards and tourists see CBT not as inferior to conventional/mass tourism. In this context, it is also important to promote more tourist education related to CBT.

The proposed strategies are merely examples of what it is possible to do and they are by no means exhaustive. Further research is required to identify strategies to promote CBT as the main approach for the tourism sector. In this context, research is needed to broaden our understanding of how government could be more influential in advancing CBT and how CBT projects could increase their size, visibility and market share.

\section{Dedication}

I dedicate this article to the late Professor Melville Saayman. Thank you Prof. for your constant encouragement, assistance, guidance... and lots of patience!

\section{References}

Acheampong, K. O. (2016). Analysing inequalities in tourism activities between local municipalities in the Eastern Cape Province of South Africa. African Journal of Hospitality, Tourism and Leisure, $5(3), 1-21$.

Akunaay, M., Nelson F., \& Singleton E. (2003). Community Based Tourism in Tanzania: Potential and Perils in Practice. Paper presented at the Second Peace through Tourism Conference 7 th $-12^{\text {th }}$ December, 2003, Dar es Salaam, Tanzania.

Ali, A. (2018). Travel and tourism: growth potentials and contribution to the GDP of Saudi Arabia. Problems and Perspectives in Management, 16(1), 417-427.

Alvaredo, F., Chancel, L., Piketty, T., Saez, E., \& Zucman, G. (Eds.). (2018). World inequality report 2018. Belknap Press of Harvard University Press.

Archer, B., Cooper, C., \& Ruhanen, L. (2005). The positive and negative impacts of tourism. In Theobald, W. F. (ed.) (2005). Global Tourism. Amsterdam: Elsevier, 79-102. 
Arnstein, S. R. (1969). A Ladder of Citizen Participation. Journal of the American Institute of Planners, 35(4), 216-224.

Asker, S., Boronyak, L., Carrard, N., \& Paddon M. (2010). Effective community based tourism: a best practice manual. APEC Tourism Working Group. Griffith University: Sustainable Tourism Cooperative Research Centre.

Bakker, M. (2018). A Conceptual Framework for Identifying the Binding Constraints to TourismDriven Inclusive Growth. Tourism Planning \& Development, DOI:10.108o/21568316.2018.1541817

Bhat, I. A. (2018). A study on environmental orientation among tourists visiting Kashmir valley. Journal of Tourism, XIX (1), 15-32.

Braun, Y. A., \& McLees, L. A. (2012). Space, ownership and inequality: economic development and tourism in the highlands of Lesotho. Cambridge Journal of Regions, Economy and Society, 5, 435449.

Britton, S. G. (1981). Tourism, Dependency and Development: a mode of analysis. Canberra: Australian National University Press.

Calanog, L. A., Reyes, D.P.T., \& Eugenio V. F. (2012). Making Ecotourism Work. A Manual on Establishing Community-based Ecotourism Enterprise (CBEE) in the Philippines. Philippines office: Japan International Cooperation Agency.

Chok, S., Macbeth, J., \& Warren, C. (2007). Tourism as a Tool for Poverty Alleviation: A Critical Analysis of 'Pro-Poor Tourism' and Implications for Sustainability. Current Issues in Tourism, $10(2 / 3), 144-165$.

Cole, S., \& Morgan, N. (2010). Introduction: tourism and inequality. In Cole, S. \& Morgan, N. (ed.) (2010). Tourism and inequality. Problems and prospects. Wallingford: CABI, xv-xxiii.

Connelly, A., \& Sam, S. (2018). How can policy assist the development of community-based tourism in Guyana by 2025 and beyond? Worldwide Hospitality and Tourism Themes, 10(5), 555-568.

Dangi, T. B., \& Jamal, T. (2008). An Integrated Approach to "Sustainable Community-Based Tourism". Sustainability, 8(475), 1-32.

Deville, A., Wearing, S., \& McDonald, M. (2016). Tourism and Willing Workers on Organic Farms: a collision of two spaces in sustainable agriculture. Journal of Cleaner Production, 111, 421-429.

Dluzewska A., \& Rodzos J. (2018). Sustainable tourism supranational policies and the wellbeing Gaps and challenges from the hosts' and the guests' perspective. Monitoring of Public Opinion: Economic and Social Changes, 5, 250-268.

Dodds, R., Ali, A., \& Galaski, K. (2016). Mobilizing knowledge: determining key elements for success and pitfalls in developing community-based tourism. Current Issues in Tourism, doi: 10.1080/13683500.2016.1150257

Duffy, R. (2015). Nature-based tourism and neoliberalism: concealing contradictions. Tourism Geographies, 17 (4), 529-543.

Faulkenberry, L.V., Coggeshall, J.M., Backman, K., \& Backman, S. (200o). A Culture of Servitude: The Impact of Tourism and Development on South Carolina's Coast. Human Organization, 59(1), 8695 .

Fennell, D.A. (2006). Tourism ethics. Clevedon: Channel View Publication.

Fletcher, R., \& Neves, K. (2012). Contradictions in Tourism. The Promise and Pitfalls of Ecotourism as a Manifold Capitalist Fix. Environment and Society: Advances in Research, 3, 60-77.

Folarin, O., \& Adeniyi, O. (2019). Does Tourism Reduce Poverty in Sub-Saharan African Countries? Journal of Travel Research. 59(1), 140-155. https://doi.org/10.1177/o047287518821736

France, L. (1997). Introduction. In France L. (ed.) (1997). The Earthscan Reader in Sustainable Tourism. London: Earthscan Publ. Ltd, 1-22. 
Gadi Djou, J. A., Baiquni, M., Widodo, T., \& Fandeli, C. (2017). Symbolic participation in communitybased tourism in Kelimutu National Park, Ende, East Nusa Tenggara. IOSR Journal of Business and Management, 19(1), 15-20.

Gartner, C., \& Cukier, J. (2012). Is tourism employment a sufficient mechanism for poverty reduction? A case study from Nkhata Bay, Malawi. Current Issues in Tourism, 15(6), 545-562.

Garza-Rodriguez, J. (2019). Tourism and Poverty Reduction in Mexico: An ARDL Cointegration Approach. Sustainability, 11(845), 1-10.

Giampiccoli, A. (2015). Community-based tourism: Origins and present trends. African Journal for Physical, Health Education, Recreation and Dance, 21(2), 675-687.

Giampiccoli, A., \& Saayman, M. (2014). A Conceptualisation of Alternative Forms of Tourism in Relation to Community Development. Mediterranean Journal of Social Sciences, 5(27), 1667-1677.

Giampiccoli, A., \& Saayman, M. (2016). Community-based tourism: From a local to a global push. Acta Commercii, 16(1), 1-10.

Giampiccoli, A., \& Saayman, M. (2017). Community-based tourism, responsible tourism, and infrastructure development and poverty. African Journal of Hospitality, Tourism and Leisure, 6(2), 1-28.

Giampiccoli, A., \& Saayman, M. (2018). Community-based tourism development model and community participation. African Journal of Hospitality, Tourism and Leisure, 7(4), 1-27.

Giampiccoli, A., Saayman, M., \& Jugmohan, S. (2014). Developing community-based tourism in South Africa: Addressing the missing link. African Journal for Physical, Health Education, Recreation and Dance, 20(3:2), 1139-1161.

Govender, I. G., \& Giampiccoli, A. (2018). Imperatives for Monitoring and Evaluation of CommunityBased Tourism: A Higher Education Institutions Perspective. African Journal of Hospitality, Tourism and Leisure, 7(2), 1-16.

Government of Barbados. (2012). Green paper on the sustainable development of tourism in Barbados: A policy framework. URL: http:// www.bhta.org/images/Download/GreenPaper.pdf

Gutierrez, E. L. M. (2019). Participation in tourism: Cases on Community-Based Tourism (CBT) in the Philippines. Ritsumeikan Journal of Asia Pacific Studies, 37, 23-36.

Hampton, M. P., Jeyacheya, J., \& Long, P. H. (2018). Can Tourism Promote Inclusive Growth? Supply Chains, Ownership and Employment in Ha Long Bay, Vietnam. The Journal of Development Studies, 54(2), 359-376.

Hamzah, A., \& Khalifah, Z. (2009). Handbook on community based tourism: How to develop and sustain CBT. Kuala Lumpur: Asia-Pacific Economic Cooperation Secretariat.

Higgins-Desbiolles, F. (2008). Justice tourism and alternative globalisation. Journal of Sustainable Tourism, 16(3), 345-364.

Higgins-Desbiolles, F. (2018). The potential for justice through tourism. Via Tourism Review, 13. URL: https://journals.openedition.org/viatourism/2469

Higgins-Desbiolles, F., Carnicelli, S., Krolikowski, C., Wijesinghe, G., \& Boluk, K. (2019). Degrowing tourism: rethinking tourism. Journal of Sustainable Tourism, DOI: 10.1080/o9669582.2019.1601732

Holden, A., Sonne. J., \& Novelli, M. (2011). Tourism and Poverty Reduction: An Interpretation by the Poor of Elmina, Ghana. Tourism Planning E Development, 8(3), 317-334.

Hongbo, W. (2013). Preface. In United Nations (2013). Inequality Matters. Report of the World Social Situation 2013. Document ST/ESA/345. New York: United Nations, Department of Economic and Social Affairs, 7-8.

Jealous, V. (1998). CBST: The Philippine perspective, criteria \& goal for each NGO/PO/Community. In Urquico, C.T. (ed.) (1998). Community based Sustainable Tourism. A handbook. Quezon City: Accessing Support Service and Entrepreneurial Technology, 8-12. 
Karim, R., Mohammad, F., \& Serafino, L. (2012). Integrating pro-poor tourism activities in a community-based idea of development: the case of the district of Hunza-Neger, Pakistan. Paper presented at the International Colloquium on Tourism and Leisure (ICTL). 9th - 12th July 2012, Bangkok, Thailand.

Kaur, P., Jawaid, A., \& Bt Abu Othman, N. (2016). The impact of Community Based Tourism on Community Development in Sarawak. Journal of Borneo Kalimantan, 2 (1), 15-26.

Khamdevi, M., \& Bott, H. (2018). Rethinking tourism: Bali's failure. IOP Conference Series: Earth and Environmental Science, 126, 1-10. doi:10.1088/1755-1315/126/1/012171

Kinyondo, A., \& Pelizzo, R. (2015). Tourism, development and inequality: The case of Tanzania. Poverty \& Public Policy, 7(1), 64-79.

Kinyondo, A., \& Pelizzo, R. (2018). Growth, employment, poverty and inequality in Tanzania. AGDI Working Paper, No. WP/18/oo1, African Governance and Development Institute (AGDI), Yaoundé.

Koens, K., \& Thomas, R. (2016). "You know that's a rip-off": policies and practices surrounding microenterprises and poverty alleviation in South African township tourism. Journal of Sustainable Tourism, 24(12), 1641-1654.

Kontogeorgopoulos, N., Churyen, A., \& Duangsaeng, V. (2014). Success Factors in Community-Based Tourism in Thailand: The Role of Luck, External Support, and Local Leadership. Tourism Planning \& Development, 11(1), 106-124.

Kravanja, B. (2012). On social inequality in tourism development and tourist marketing of postcolonial Sri Lanka. Studia ethnologica Croatica, 24, 107-129.

López-Guzmán, T., Sánchez-Cañizares, S., \& Pavón, V. (2011). Community-based tourism in developing countries: a case study. Tourismos: An International Multidisciplinary Journal of Tourism, 6(1), 69-84.

Mahadevan, R., Amir. H., \& Nugroho, A. (2017). Regional impacts of tourism-led growth on poverty and income: Inequality: A dynamic general equilibrium analysis for Indonesia. Tourism Economics, 23(3), 614-631.

Mayaka, M., Croy W. G., \& Wolfram Cox, J. (2018). Participation as motif in community-based tourism: a practice perspective. Journal of Sustainable Tourism, 26(3), 416-432.

Mayaka, M., Croy W. G., \& Wolfram Cox, J. (2019). A dimensional approach to community-based tourism: Recognising and differentiating form and context. Annals of Tourism Research, 74, 177190.

Mogale, P. T., \& Odeku, K. O. (2018). Transformative tourism legislation: an impetus for socioeconomic development in South Africa. African Journal of Hospitality, Tourism and Leisure, 7(3), 1-16.

Moscardo G. (2008). Building community capacity for tourism development: Conclusion. In Moscardo, G. (ed.), Building community capacity for tourism development. Wallingford: CAB International, pp. 172-179.

Mowforth, M., Charlton, C., \& Munt, I. (2008). Tourism and responsibility perspectives from Latin America and the Caribbean. London: Routledge.

Mtapuri, O., \& Giampiccoli, A. (2013). Interrogating the role of the state and nonstate actors in community-based tourism ventures: toward a model for spreading the benefits to the wider community. South African Geographical Journal, 95(1), 1-15.

Mtapuri, O., \& Giampiccoli, A. (2016), Towards a comprehensive model of community-based tourism development. South African Geographical Journal, 98(1), 154-168.

Mtapuri, O., \& Giampiccoli, A. (2017). A conceptual coalescence: towards luxury community-based tourism. African Journal of Hospitality, Tourism and Leisure, 6(3), 1-14. 
Mtapuri, O., \& Giampiccoli, A. (2019). Tourism, community-based tourism and ecotourism: a definitional problematic. South African Geographical Journal, 101(1), 22-35.

Nagarjuna, G. (2015). Local Community Involvement in Tourism: A Content Analysis of Websites of Wildlife Resorts. Atna, Journal of Tourism Studies, 10(1), 13-21.

Naik, S. (2014). Community based tourism approach - a review. Compass, 1(2), 42-47.

Ndlovu, J., Nyakunu, E., \& Auala, S. (2011). Community based tourism in Twyfelfontein conservancy: Exploring local community's involvement. International Journal of Hospitality $\mathcal{E}$ Tourism Systems, 4(2), 38-46.

Ndlovu, N., \& Rogerson, C. M. (2004). The local economic impacts of rural community-based tourism in Eastern Cape. In Rogerson C. M., \& Visser G. (eds.) (2004). Tourism and development issues in contemporary South Africa. Pretoria: Africa Institute of South Africa, 436-451.

Neth, B., Rith, S., \& Knerr, B. (2008). Global environmental governance and politics of ecotourism: case study of Cambodia. Paper presented at $12^{\text {th }}$ EADI General Conference. Global governance for sustainable development. The need for policy coherence and new partnerships. Geneva, 24-28 June 2008.

Niemhom, N. (2018). Executive summary. In UNWTO (2018). Inclusive Tourism Destinations Model and success stories. Madrid: World Tourism Organisation, 9-11.

Okazaki, E. (2008). A Community-based tourism model: Its conception and use. Journal of Sustainable Tourism, 16(5), 511-529.

Pearce, D. (1989). Tourism development. Harlow: Longman.

Pérez, F. J., Barrera, O. D., Peláez, A. V., \& Lorío, G. (2010). Turismo Rural Comunitario Como Alternativa de educción de la Pobreza Rural en Centroamérica. Edificio Nitlapan Campus de la UCA Managua, Nicaragua.

Petit, S. (2017). International trade in services and inequalities: empirical evaluation and role of tourism services. Tourism Economics, 23(5), 1069-1075.

Raza, S. A., \& Shah, N. (2017). Tourism growth and income inequality: does Kuznets Curve hypothesis exist in top tourist arrival countries. Asia Pacific Journal of Tourism Research, 22(8), 874-884.

Reyes, J. (2011). The roles of sustainable tourism in neoliberal policies and poverty reduction strategies: do they adequately address quality of life? The Applied Anthropologist, 31(1), 23-29.

Risso, W. A. (2018). Tourism Specialization, Income Distribution, and Human Capital in South America [Online First], IntechOpen. doi: 10.5772/intechopen.82002. URL: https://www.intechopen.com/online-first/tourism-specialization-income-distribution-andhuman-capital-in-south-america

Rogerson, C. M., Benkenstein, A., \& Mwongera, N. (2018). Coastal tourism and economic Inclusion in Indian Ocean Rim Association states. Global Economic Governance (GEG) Africa, Discussion Paper, October 2018.

Saayman, M., \& Giampiccoli, A. (2016). Community-based and pro-poor tourism: Initial assessment of their relation to community development. European Journal of Tourism Research, 12, 145-190.

Sakata, H., \& Prideaux, B. (2013). An alternative approach to community-based ecotourism: a bottomup locally initiated non-monetised project in Papua New Guinea. Journal of Sustainable Tourism, 21(6), 880-899.

Scheyvens, R. (200o). Promoting Women's Empowerment through involvement in Ecotourism: Experiences from the Third World. Journal of Sustainable Tourism, 8(3), 232-249.

Scheyvens, R. (2011). Tourism and poverty. London: Routledge.

Scheyvens, R., \& Biddulph, R. (2018). Inclusive tourism development. Tourism Geographies, 20(4), 589609.

Schilcher, D. (2007). Growth versus equity: the continuum of pro-poor tourism and neoliberal governance. Current Issues in Tourism, 10(2), 166 -193. 
Signé, L. (2018). Africa's tourism potential. Trends, drivers, opportunities, and strategies. Africa Growth Initiative, Brookings Institution.

Singh, L. K. (2008). Ecology, Environment and Tourism. ESHA Books: Delhi.

Somnuek, P. (2018). Development of transboundary networking pattern of community-based tourism in Ubon Ratchathani province (Thailand). International Journal of Sustainable Development and Planning, 13(8), 1029-1040.

Sproule, K.W., \& Suhandi, A.S. (1998). Guidelines for community-based ecotourism programs: lessons from Indonesia. In Lindberg, K., Epler Wood, M., \& Engeldrum, D. (eds.) (1998). Ecotourism: A Guide for Planners and Managers. Volume 2. The Ecotourism Society, North Bennington, Vermont, 215-235.

Suansri, P. (2003). Community Based Tourism Handbook. Bangkok: Responsible Ecological Social Tour-REST.

Suansri, P., \& Yeejaw-haw, S. (2013). Community-based tourism standard handbook. Chaing Mai: The Thailand Community-based tourism institute.

Tasci, A. D. S., Semrad, K. J., \& Yilmaz, S. S. (2013). Community based tourism finding the equilibrium in COMCEC context: Setting the Pathway for the Future. Ankara: COMCEC Coordination Office.

The Department of Environmental Affairs and Tourism. (1996). White Paper on the Promotion and Development of Tourism in South Africa. Pretoria: DEAT.

Tolkach, D., \& King, B. (2015). Strengthening Community-Based Tourism in a new resource-based island nation: Why and how? Tourism Management, 48, 386-398.

Tolkach, D., King, B., \& Pearlman, M. (2011). The Prospects for a Community-Based Tourism Network in Timor-Leste. CAUTHE National Conference. Tourism: Creating a brilliant blend, 8-11 February 2011, University of South Australia, Adelaide.

Tosun, C., Timothy, D. J., \& Öztürk, Y. (2003). Tourism growth, national development and regional inequality in Turkey. Journal of Sustainable Tourism, 11(2-3), 133-161.

Trejos, B., Chiang, L. H. N., \& Huang, W. C. (2008). Support networks for community-based tourism in rural Costa Rica. The Open Area Studies Journal, 1(1), 16-25.

Triarchi, E. I., \& Karamanis, K. (2017). The evolution of alternative forms of Tourism: a theoretical background. Business E Entrepreneurship Journal, 6(1), 39-59.

Ullan de La Rosa, F. J., Aledo Tur, A., \& Garcia Andreu, H. (2017). Community-Based Tourism and the Political Instrumentalization of the Concept of Community. A New Theoretical Approach and an Ethnographical Case Study in Northeastern Brazil. Anthropos, 112, 467-486.

UN. (2013). Inequality Matters. Report of the World Social Situation 2013. Document ST/ESA/345. New York: United Nations, Department of Economic and Social Affairs.

UN. (2019). World Economic Situation and Prospects 2019. New York: United Nations.

UNWTO. (2011). Tourism towards 2030 / Global Overview. Madrid: World Tourism Organisation.

UNWTO. (2018a). Tourism Highlights, 2018 Edition. Madrid: World Tourism Organisation.

UNWTO. (2018b). Inclusive Tourism Destinations Model and success stories. Madrid: World Tourism Organisation.

WEF. (2018). The Inclusive Development Index 2018 Summary and Data Highlights. URL: http://www3.weforum.org/docs/WEF_Forum_IncGrwth_2018.pdf

Wiranatha, A. S., Antara, M., \& Suryawardani, I. G. A. O. (2017). Impact of Tourism Leakage on the Growth of Economic Sectors, Employment and Income Distribution in Bali, Indonesia.

International Journal of Economic Research, 14(8), 11-27.

WTTC. (2018). Power \& Performance Rankings. London: World Travel \& Tourism Council. URL: https://www.wttc.org/-/media/files/reports/2018/power-and-performance-rankings-2018.pdf

Yang, L. (2018). The relationship between poverty and inequality: Resource constraint mechanisms. CASEpaper211/LIPpaper5. Centre for Analysis of Social Exclusion, London School of Economics. 
Received: 03/09/2019

Accepted: 16/11/2019

Coordinating editor: Stanislav Ivanov 